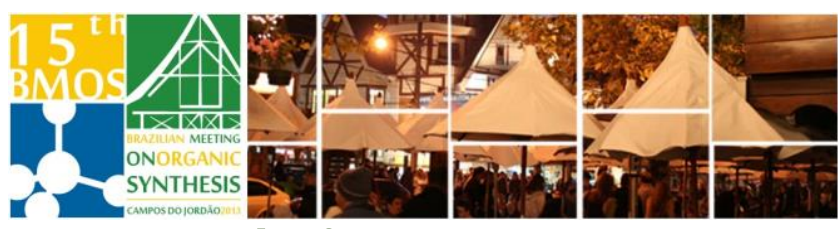

\title{
Enantioselective catalysis from Pseudomonas cepacia on the kinetic resolution by different reactors
}

\section{Evelin A. Manoel ${ }^{1^{*}}(\mathrm{PG})$, Maria Alice Z. Coelho ${ }^{1}(\mathrm{PQ})$, Rodrigo O. M. A de Souza ${ }^{2}$} $(P Q),(P Q)$ Alessandro B.C. Simas ${ }^{4}(P Q)$ and Denise M.G. Freire ${ }^{3}(P Q)$.

1 Universidade Federal do Rio de Janeiro, Escola de Química, Departamento de Engenharia Bioquímica. 2 Universidade Federal do Rio de Janeiro, Instituto de Química, Departamento de Química Orgânica. 3 Universidade Federal do Rio de Janeiro, Instituto de Química, Departamento de Bioquímica ${ }_{4}$ Universidade Federal do Rio de Janeiro, Núcleo de Pesquisas de Produtos Naturais (NPPN). *evelin@ufri.br/biorecados@yahoo.com.br

Keywords: Biocatalysis, myo-inositol, batch reactor, continuous flow reator

\section{INTRODUCTION}

Enantioselective catalysis is an area of expertise that has been receiving increasingly attention. Its success depends on several factors, such as specificity of the biocatalyst, type of immobilization, substrate, solvent, and reactor systems. ${ }^{1,2}$

Currently, most of the studies in the literature report the use of reactors in small scale stirred tank on batch system ${ }^{3}$. In this way, the phosphorylated myo-inositols appear as interesting substrates, to be studied due to their potential in the development of new drugs. The phosphorylated myo-inositols play key roles in fundamental biological phenomena such as cellular signal transduction. ${ }^{4-5}$

The present work aims at the use from immobilized Pseudomonas cepacia lipase on the efficient kinetic resolution of $( \pm)$-1,3,6-tri- $O$-benzilmyo-inositol (mio- $l)^{1}$, a precursor known of $1 \mathrm{D}-2,4,5$ myo-inositol trisphosphate ${ }^{4}$, a bioactive substance and a potential one for other inositol bisphosphates and trisphosphates. The biocatalytic continuous flow process and the batch process by alcoholysis reaction were investigated (Figure 1).

\section{RESULTS AND DISCUSSION}

The study of the kinetic resolution of mio-l was made employing vinyl acetate as the acylating agent in solvent-free media like previously studied. The reactions were carried out by batch system and showed the monoacetate L-5-O-acetil-1,3,4-tri-Obenzyl-myo-inositol (L-2) formation after 48 hours of reaction time. The experiment had a good yield $(48,9 \%)$. On the other hand, the reactions carried out by continuous flow system presented $18,87 \%$ of conversion in 3min of reaction time. Both operational systens presented high enantiomeric excesses and enantiomeric ratio (ee>99\% and E>200, respectively).

Although the reactions in continuous flow system presented lower yields than those in batch system, $\left(0,001 \mathrm{mg}\right.$ product $\left./ \mathrm{mg}_{\text {enzyme. }}\right)$, the productivity increased 426-fold for continuous flow system $(0,426 \mathrm{mg}$ product/mgenzyme.h), when compared to the batch system.
Figure 1. Kinetic resolution of mio-I catalyzed by PS-IM in free solvent media using different reactors. Batch system conditions: $50 \mathrm{mg}$ of enzyme, $5 \mathrm{mg}$ of substrate, $2,5 \mathrm{~mL}$ of vinyl donor, at 48hours.

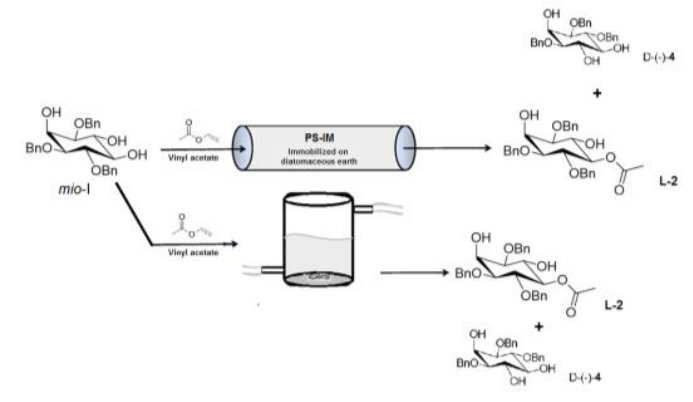

Table 1. Kinetic resolution of mio-I (Figure 1) catalyzed by PS-IM in continuous flow conditions (mio-inositol/acetato de vinila=1:66 mM).

\begin{tabular}{|c|c|c|c|c|}
\hline Temperature & Flow taxa & $X \%$ & $e e_{p}(\%)$ & $\mathrm{E}$ \\
\hline \multirow{2}{*}{$30^{\circ} \mathrm{C}$} & $0,5 \mathrm{~mL} / \mathrm{min}$ & $1,12 \pm 0,380$ & $\cdots$ & $\ldots$ \\
\hline & $1,0 \mathrm{~mL} / \mathrm{min}$ & $0,56 \pm 1,360$ &.- & $\cdots$ \\
\hline \multirow{2}{*}{$40^{\circ} \mathrm{C}$} & $0,5 \mathrm{~mL} / \mathrm{min}$ & $18,87 \pm 0,005$ & $>99$ & $>200$ \\
\hline & $1,0 \mathrm{~mL} / \mathrm{min}$ & $5,81 \pm 0,042$ & 96,5 & 65,5 \\
\hline \multirow{2}{*}{$50^{\circ} \mathrm{C}$} & $0,5 \mathrm{~mL} / \mathrm{min}$ & $2,45 \pm 0,328$ & $\cdots$ & $\ldots$ \\
\hline & $1,0 \mathrm{~mL} / \mathrm{min}$ & $1,23 \pm 0,018$ & $\cdots$ & $-\cdots$ \\
\hline
\end{tabular}

The efficient protocol for the resolution of mio-I in our study makes the synthesis of both enantiomorphs (and derivatives) very practical and with high optical purity. The biocatalyst PS-IM was able to catalyze the kinetic resolution of myo-I in both reactors used.

\section{ACKNOWLEDGEMENTS}

The Faperj, CNPq and Capes by financial support.

\section{REFERENCES}

${ }^{1}$ Manoel, E.A.; Paes, K.C.; Cunha, A.G.; Coelho, M.A.Z.; Freire, D.M.G. e Simas, A.B.C., Tetrahedron: Asymm., 2012, 23, 47.

${ }^{2}$ Manoel, E.A., Pais, K.C., Flores, M.C., Miranda, L.S.M., Coelho, M.A.Z., Simas, A.B.C., Freire, D.M.G. e Souza, R.O.M.A. J. Mol.Cat. B: Enzym., 2013, 87, 139.

${ }^{3}$ Boros, Z.; Falus, P.; Márkus, M.; Weiser, D.; Oláh, M.; Hornyánszky, G.; Nagy, J. e Poppea, L. J. Mol.Cat.B: Enzym., 2013, 85-86, 119.

${ }^{4}$ Almeida, M.V., Silva, D.S., Souza, M.V.N. e Benício, A.A.A. Quim. Nova, 2003, 26, 105.

${ }^{5}$ Oliveira, M.M.; Einicker-Lamas, M. Anais da Academia Brasileira de Ciências, $\quad$ Brasil, $\quad$ 2000, $\quad 42, \quad 413$ 